\title{
A preliminary response from the Faculty of Psychology students of the University of Cuenca to the modified EFL teaching approach
}

\author{
Marcelo Bernal ${ }^{1,2}$, Jan Feyen ${ }^{3}$ \\ ${ }^{1}$ Facultad de Psicología, Universidad de Cuenca, Cuenca, Ecuador. \\ 2 Instituto Universitario de Lenguas, Universidad de Cuenca, Cuenca, Ecuador. \\ ${ }^{3}$ Dirección de Investigación de la Universidad de Cuenca (DIUC), Cuenca, Ecuador. \\ Autor de correspondencia: marcelo.bernal@ucuenca.edu.ec \\ Fecha de recepción: 10 agosto 2016 - Fecha de aceptación: 5 de mayo 2017
}

\begin{abstract}
English teachers in Ecuadorian universities, like teachers in many non-native English-speaking countries, face the challenge of dealing with uninterested, unmotivated students, even when intermediate proficiency of English is a basic requirement for graduation. As from the end of 2014, the Faculty of Psychology of the University of Cuenca modified the English as a Foreign Language (EFL) instruction at the three proficiency levels of English learning, by linking the training in reading to the reading of major related material and stimulating the students to practice actively the four English language skills outside the classroom using website and video hosting sites. At the end of 2016, the students' impressions of being exposed to the modified way of student-centered instruction were assessed using a questionnaire. A total of 106 students completed online the 10-question survey. Results showed the enthusiasm of the students towards the modified more dynamic and interactive mode of EFL instruction; appreciated that more autonomy and responsibility were given to the students, and suggested that focus on grammar should not be neglected. An important side effect of the approach was the indirect harnessing of listening, writing, reading and speaking skills as well as skills in the reading and analysis of thematic research papers; considered an important benefit for the thesis project.
\end{abstract}

Keywords: EFL, student-centered instruction, reading, research articles, Faculty of Psychology.

\section{RESUMEN}

Profesores universitarios ecuatorianos de inglés, al igual que aquellos en muchos países no hablantes de lengua inglesa, enfrentan el reto de tratar con estudiantes desinteresados y desmotivados, aun cuando poseer habilidades intermedias del inglés es un requisito básico de graduación. A partir de finales del 2014, la Facultad de Psicología de la Universidad de Cuenca modificó la enseñanza de inglés como lengua extranjera (ILE) en los tres niveles de competencia, vinculando la lectura a la lectura de material relacionado a sus carreras y estimulando a los estudiantes a practicar activamente el aprendizaje del inglés fuera del aula usando sitios en internet para la práctica de las cuatro habilidades del idioma. Al final del semestre del 2016, las impresiones de estar expuestos a esta forma modificada de instrucción centrada en el estudiante se evaluaron mediante un cuestionario. Un total de 106 estudiantes completaron en línea una encuesta de 10 preguntas. Los resultados mostraron el entusiasmo de los estudiantes hacia este nuevo modelo más dinámico e interactivo modificado de la enseñanza del ILE. Hubieron muestras de reconocimiento de que se diera más autonomía y responsabilidad a los estudiantes, y se sugirió que el enfoque en la gramática no debe ser descuidado. Un efecto secundario importante de esta metodología fue el aprovechamiento y la mejora indirecta en las habilidades de escuchar, escribir, leer y hablar, así como habilidades en la lectura y análisis de trabajos de investigación, considerado un importante beneficio para el proyecto de tesis.

Palabras clave: ILE, instrucción centrada en el estudiante, lectura, trabajos de investigación, Facultad de Psicología 


\section{INTRODUCTION}

Quite an extensive volume of literature is available on how English as a foreign language is most effectively taught. Larsen-Freeman and Long (1991), cited by Menesez (2013), indicated that at least forty "theories" of Second Language Acquisition (SLA) have been proposed (p.227), and it is her belief that none of them has been able to explain the language teaching phenomenon. She also pointed out that these theories mainly emphasize on the acquisition of language structures leaving out very important aspects of a language. Amongst the countless SLA theories, she states that eight are the most important ones that caused a significant impact in the field and are important for further consideration. They are the behaviorism, acculturation, universal grammar hypothesis, comprehension hypothesis, interaction hypothesis, output hypothesis, sociocultural theory, and connectionism.

In the Ecuadorian university context, English instruction is predominantly docent centered, and the structure and content of the English curricula are still considerably top-down controlled and defined by the Consejo de Educación Superior (CES, 2016) and the administration of the Language Department within the universities. Not surprisingly that the English language programs are seldom responding to today's students' need for English proficiency. The situation on the ground is that students attend the three levels of English instruction simply because it is a compulsory academic requirement for graduation. Due to the overweight in the traditional training on grammar, vocabulary, and the discussion of non-major related aspects, and above all due to the passive role of the student in class, the students' competence in English language at graduation is low to modest.

The interest in language learning at the beginning of this century is on the rise primarily because of the increasing societal diversity, and the academic and cognitive benefits of being proficient in a foreign language (Pop \& Sim, 2013). To catch the students' interest to learn English, the students should be stimulated to learn inside and outside the classroom. Oral classroom tasks should be a major component of English instruction, and participation in these tasks are a must to improve their reading, listening and speaking skills. It is generally recognized that language learning is enhanced when the level of interaction increases when students are given the opportunities to be creative, curious and the center of language learning. On the other hand, Matute (2005) states that reading is often chosen as an English as Foreign Language (EFL) activity in undergraduate and scientific studies. This approach, a pedagogical tool to learn a foreign language, emphasizes on the capacity to learn how to read and comprehend the language. Very few grammatical explanations, as well as pronunciation, language fluency, and vocabulary exercises, are only given when necessary to understand the content. Codeswitching and translation exercises are part of this approach to assure that the students fully comprehend the reading material.

Brevik (2014, 2016) and Duke et al. (2011) indicated that reading for specific purposes can engage students in careful reading in contextualized settings to understand the language lexicon or careful reading at the global level to understand the main ideas of a text. In fact, the ability to adjust one's reading to a specific purpose is a key reading requirement in the Norwegian-English syllabus (Norwegian Directorate of Education and Training, 2010). Richard \& Smith (2002) recommended the incorporation of reading practices in regular English courses, which encourages the knowledge of grammar structures and vocabulary, and the love of reading. Additionally, Pluck (2013) mentioned that the introduction of reading of academic articles in English teaching presents additional challenges for students and instructors, but the overall benefits are noteworthy. Krashen (2004) indicated that juniors and adults who practice recreational reading show better development in reading, writing, grammar, and vocabulary. To increase students' participation, motivation and commitment towards learning English and to become independent users, Feyen (2013) pointed out that it is necessary to develop the four language skills: listening, speaking, reading and writing. To increase reading, he suggested that part of the English language training should be focused on the reading of articles related to their major and the development of a summary of the reading material to enhance student's writing proficiency. Further, the instructor should invite the students to give an oral presentation on the read article, to listen to comments and suggestions from the teacher and to discuss with classmates.

The inclusion in the EFL instruction of the reading of major related articles offers the advantage that the students most likely are more motivated, and in addition, by doing so the students learn how to read research papers, a beneficial training in preparation of the thesis project in the final year of the 
undergraduate program. As stated by Meyer (2014) is Ing. Pablo Vanegas (PhD), the president of UC, of the opinion that reading and writing major related English text material should be the foundation of EFL curriculum, since the other language skills, listening and speaking, will incidentally develop.

Based on these considerations the English language courses coordination of the Faculty of Psychology decided in 2014 to include as a significant part in the three levels of EFL instruction credits for reading, writing, presentation and discussion of one to several major related research papers. In addition, students are stimulated to learn on their own by actively using website and video-type based English material. The aim of this article is to report on the preliminary impressions of the students regarding the modified instruction model of EFL teaching in the Faculty of Psychology. The hypotheses of the study are: (i) students' attitudes toward learning English improves when the reading embraces the analysis of major related research papers; (ii) more autonomy is given to the students in the learning process by widening the study material to material freely available in the Internet; and (iii) to link the development of the other language skills, like writing and speaking, to the reading of research papers.

\section{EFL TEACHING: CLASSICAL VERSUS A READING/PRESENTATION APPROACH}

\subsection{EFL training in Ecuadorian universities}

Traditionally, the teaching of English language at university level in Ecuador focuses on developing grammar skills, and the training in isolated concepts responding to different realities and contexts depicted in EFL/ESL commercial English textbooks ${ }^{1}$. Students are trained at three subsequent levels of English, respectively level I (elementary), II (beginning) and III (pre-intermediate); the three levels of English Instruction are mandatory requirements for graduation in any major of the University of Cuenca (UC). Each level comprises 96 hours of instruction (6 hours weekly for 16 weeks, the duration of one semester), and the students are required to go through the three levels. The students are free to determine the semester they will dedicate to study English and harness credits. They can start with level I in the $1^{\text {st }}$ semester of the undergraduate program, or defer attending the class of level I till for example the $4^{\text {th }}$ semester or even until the end of the undergraduate program. However, it is the student's responsibility to finish level III before graduation.

In general, English programs lack fundamental principles and structure. Content and methodology are teacher centered and based on commercial English language books. Traditionally, the English Institution Administration or the English language courses coordination assigns to the English instructors the course material and recommends the methodology they should use. This approach resulted in a conscious and unconscious conditioning of both teachers and students that teaching and learning English comes down to the teaching of grammar rules and the mastering of several poorly integrated concepts. The process is entirely teacher-controlled, and the reality is that most English courses demotivate, frustrate and bore students, often leading to an aversion to learning English. The students in general possess at graduation a low to moderate knowledge of English language and poorly master English reading, listening, communication and writing skills.

\subsection{EFL training based on a reading/presentation approach}

The EFL training adopted by the Faculty of Psychology of UC is structurally organized in the same way as the traditional approach, namely 3 proficiency levels of EFL, each level being taught during a semester ( 16 weeks, 6 hours a week), the students must accomplish the 3 levels before graduation, and the students freely choose when to start with level I and end with level III.

The specific objectives of the remodeled EFL training in the Faculty of Psychology for each of the three proficiency levels I, II, and III are: i) students use the four language competencies (reception,

\footnotetext{
1 EFL/ESL: English as a foreign language / English as a second language When using commercial English textbooks, students are introduced to pictures, images, stories, readings, listening and speaking exercises that do not belong to the local context and realities. They might be reading, listening, speaking and writing about Madonna, Nepal, or some other issues.
} 
production, interaction and mediation) at the $\mathrm{A} 1, \mathrm{~A} 2$ and $\mathrm{B} 1$ level $^{2}$ of the $\mathrm{CEFRL}^{3}$ at a $75 \%$ proficiency; ii) read, understand, discuss and present scientific texts related to Psychology and general English; iii) have mastery of 1000+, 2000+ and 3000+ words related to Psychology and general English in first, second and third level respectively; and iv) present orally and in writing what is being learned during the course according to the parameters required by level A1, A2 and B1 of CEFRL (Trim et al., 2001).

The main difference of the new approach versus the classical way of teaching is the applied instruction methodology. Each level of English language instruction is based on the selection by the students in close consultation with the instructor of a psychology related scientific or academic article, which the student must read, analyze, summarize and present. The English instructor introduces the students how to read the articles; students are shown how to skim, scan and mine a research paper (Tsai, 2006). Simultaneously, the English instructor provides explanations how to read, highlights the unknown words, and practices grammar in context corresponding to the CEFRL levels. Capacity in writing in accordance with the level of instruction (I, II and III) is generated by the writing of a 120, 200 or 300-word summary of the read and analyzed article, which the students must present and share with their classmates. Other class activities are a chat session; a true-false statement section whereby the students need to go back to their article to find the right answer; a synonym match where unknown words in the article are matched with their synonym; a phrase-match section; a spelling section; and a discussion section.

In addition to the time spent in class, students are stimulated to practice on their own rhythm one of the following activities: i) Tedtalkazos ${ }^{4}$ : offering online lectures in English about different topics; ii) ReadTheory ${ }^{5}$ : a virtual reading platform that facilitates and promotes autonomous reading; iii) Youtubazo, a term coined by a student of the Hospitality School of UC in 2011, that consists of listening to their favorite song on Youtube for practicing English; iv) Voscreen.org ${ }^{6}$ : enables students to practice listening, pronunciation, reading and comprehension exercises; v) Show and Tell: an educational form whereby students present in the class one of their favorite objects; vi) PSYTalks\&Music ${ }^{7}$ : a series of talks in English on a variety of topics by students, staff and special guests in which the University's community can freely participate; vii) WhatsApp ${ }^{8}$ and Facebook groups of students and English instructors practicing informal English through text messaging. The regular rehearsal of one to several of those side activities allows the students to train pronunciation, vocabulary, intonation, rhythm, and grammar and sentence structures outside the classroom.

\section{POPULATION AND DATA COLLECTION}

Out of 179 students taking the three levels of English at the Faculty of Psychology of UC, 106 students participated in a survey. The inquiry was conducted in the period January-February 2017 and consisted of a Google type questionnaire, of which the students received the survey link via email to ensure anonymity. The questionnaire consisted of 3 sections, respectively a section to collect general data of the participants (age, sex, field of study and semester enrolled), a section probing the level of English each participant is in, and a section gauging the participants' appreciation of the new learning method of English and their preferences. This section consisted of 8 Likert-scale questions and two open-ended

2 A1, A2 and B1 level: Are the English levels with their corresponding competencies determined by the CEFRL (http://europass.cedefop.europa.eu/sites/default/files/cefr-en.pdf).

3 CEFRL: The Common European Framework of Reference for Languages.

4 TedTalkazos: A term coined by one of the English Instructors meaning students and instructor listen to one or two talks per week at https://www.ted.com/talks.

5 https://readtheory.org/

6 VOScreen.org is a web site provided by one of the psychology students in 2016.

7 PSYTalks\&Music: https://www.ucuenca.edu.ec/recursos-y-servicios/prensa/3739-psytalks-music-terceraedicion.

8 Whatsapp: an ad-free instant messaging service for smartphones.

9 Facebook: a free social networking website that allows registered users to create profiles, upload photos and video, send messages and keep in touch with friends, family and colleagues. 
questions. The questions 1 to 4 probed towards the participants' preference and reasons to study English as a foreign language, while the questions 5 to 8 aimed to identify the students' attitude towards the reformed English language teaching at the faculty, and if the new teaching model was helpful. Question 9 identified the students' preference of teaching activity, and question 10 aimed to collect students' comments and suggestions about the reformed English teaching approach.

Data was gathered on line through the automatic version of the Google form application. The first eight Likert-scale questions (column 2 to 8 in Table 2), with the options, strongly agree (SA), agree (A), in some manner agree (SmA), disagree (D), and strongly disagree (SD), reported the students' response expressed as the percentage. The students' preferences (question 9) and comments/suggestions (question 10 ) are discussed in the text and presented as percentages.

\section{RESULTS}

Characteristics of the student population that participated in the survey are listed in Table 1. Most of the 106 participating students, $66.1 \%$, were in the age group $18-22,28.3 \%$ were 23 to 26 years old, and a minority of the surveyed population was older varying between 27-30 years (1.9\%), 31-35 (2.8\%) and $36-40(0.9 \%)$. Gender-wise $58.5 \%$ of the surveyed students were female and $41.5 \%$ male. The majority of students enrolled in the first three semesters in one of the three level courses of EFL, whereas in the fourth, fifth and sixth semester on average around $10 \%$ of the participants were following a level course, and a minor fraction of students still enrolled in an EFL level course in the three last semesters of the undergraduate program.

Table 1. Population distribution according to age, sex, field of study and semester enrolled.

\begin{tabular}{cccccccc}
\hline \multicolumn{2}{c}{ Age } & \multicolumn{2}{c}{ Sex } & \multicolumn{2}{c}{ Field of study } & \multicolumn{2}{c}{ Semester enrolled } \\
Years & Percent & Gender & Percent & Majors & Percent & Semester & Percent \\
\hline $18-22$ & 66.1 & Male & 41.5 & Clinical Psychology & 48.1 & First & 21.7 \\
$23-26$ & 28.3 & Female & 58.5 & Educational Psychology & 24.5 & Second & 19.8 \\
$27-30$ & 1.9 & & & Social Psychology & 17 & Third & 18.9 \\
$31-35$ & 2.8 & & & Others & 10.4 & Fourth & 10.4 \\
$36-40$ & 0.9 & & & & & Fifth & 11.3 \\
& & & & & & Sixth & 9.4 \\
& & & & & Seventh & 1.9 \\
& & & & & Eight & 2.8 \\
& & & & & Nine & 3.8 \\
\hline
\end{tabular}

As shown in Table 2 are the majority of the students (up to 90\%) convinced that proficiency in English is beneficial for their future career, for making personal and academic progress. Notwithstanding, is the group of students with a positive attitude towards the learning of English a bit lower, ranging around $78.5 \%$, and the group of students that really likes English amounts $73.9 \%$. The group of students that do not like or strongly don't like studying English is less than 5\%, a minority. The survey also revealed that more than $75 \%$ of the students strongly like the new teaching approach adopted by the Faculty, it is whereby the EFL training is connected to the field of Psychology by accommodating the students to learn reading and analyzing English research papers in the broad field of Psychology, and in writing a synopsis of the manuscript and presenting orally this synopsis. Simultaneously to the focus on research papers, attention in the EFL training is given to the learning of words, aspects of grammar, writing, making oral presentations and discussing. 
Table 2. Relative distribution (\%) according to the Likert-scale of the response of the respondents to the online questionnaire.

\begin{tabular}{|c|c|c|c|c|c|c|c|c|}
\hline 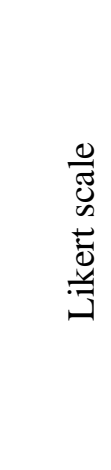 & 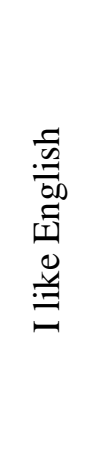 & 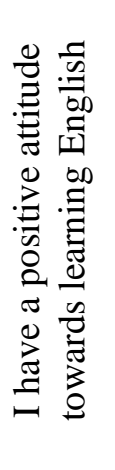 & 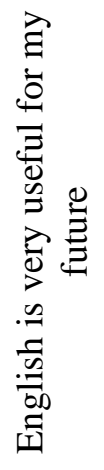 & 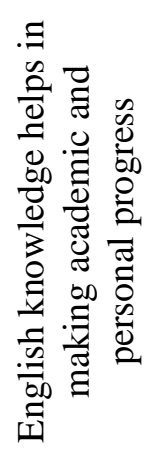 & 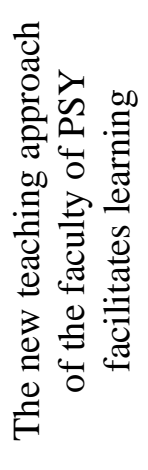 & 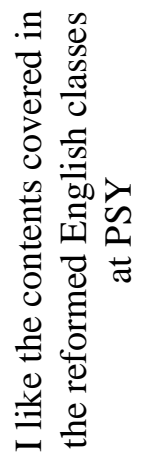 & 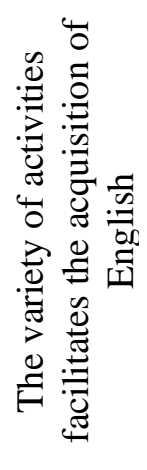 & 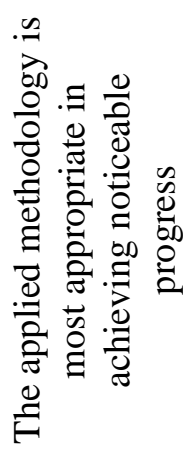 \\
\hline SA & 29.0 & 24.3 & 57.9 & 52.3 & 41.1 & 43.0 & 43.0 & 44.9 \\
\hline A & 44.9 & 54.2 & 30.8 & 40.2 & 37.4 & 31.8 & 34.6 & 29.9 \\
\hline SmA & 21.5 & 17.8 & 6.5 & 0.0 & 15.0 & 18.7 & 16.8 & 17.8 \\
\hline D & 4.7 & 2.8 & 1.9 & 5.6 & 4.7 & 5.6 & 3.7 & 4.7 \\
\hline SD & 0.0 & 0.9 & 2.8 & 1.9 & 1.9 & 0.9 & 1.9 & 2.8 \\
\hline
\end{tabular}

Note: $\mathrm{SA}=$ strongly agree, $\mathrm{A}=$ agree, $\mathrm{SmA}=$ in some manner agree, $\mathrm{D}=$ disagree, $\mathrm{SD}=$ strongly disagree

The survey also revealed that listening, reading, and writing are more beneficial in learning the English language than for example speaking and signing. Focusing EFL training on grammar and vocabulary seems to have the least effect. Whereas most of the surveyed students feel positive about the remodeled approach of EFL training, a minor percentage of the students like receiving more instruction in grammar, less use of journals and a further improvement of the methodological approach.

\section{DISCUSSION}

The objective of the study was to assess the students' perception of a new, rather unconventional approach of English teaching that better responds to the students' demands and needs at the Faculty of Psychology of UC. The new form of EFL teaching has been implemented since the second semester of 2014 and the survey was applied during January to February 2017, at the three proficiency levels (I, II and III). More than $75 \%$ of the students reported they liked the modified approach of teaching more than the conventional way English is taught. The positive reactions to the remodeling of the English program must be that students' attitudes changed since they had the opportunity to realize they made better progress in both written and oral proficiency in the English language. The new approach helped the students to recognize that learning and researching in English are everywhere and can be more efficiently learned by linking the EFL training to the material taught in the students' major. A student commented ${ }^{10}$ : "All right! The English class I like because of the new approach, which I never experienced before, and given the infancy of the approach for sure the method can be further improved". Another student stated: "The modified approach is considerably more interactive and linked to the subjects taught in our major, which I like a lot and I clearly noticed the difference in instruction and learning from the first level". Other comments communicated by the students were: "In my opinion, I think it is a new and important way to learn the language and in addition the instruction topics are directly related to the career of Psychology", and "The new approach is excellent because it stimulated me to really learn English". The incorporation of major related reading material in the English instruction at the three levels seems to lead to an encouragement of the students to learn and improve their grammar and vocabulary in context, speaking and writing skills. It represents an important

\footnotetext{
${ }^{10}$ Students' comments have been edited by the authors.
} 
component in English courses at the university level as stated by Richard \& Smith (2002), Pluck (2013) and Krashen (2004).

Feyen (2013) recommends the incorporation in EFL courses of English major related material as practice of the four language skills: i) in reading, students should read extensively and intensively topics related to their major not just in English classes but in their regular ones as well; ii) in writing, students should be able to prepare accurate summaries of what they have read; iii) in speaking, students should present orally the summary of the material read, and iv) in listening, students should listen to their instructors and peers' comments and presentations. Similarly, Mckinley (2010) in his research about what English do University students need?, he pointed out that what they really need is: i) to understand lectures in English and take effective notes in real time, i.e. not recording it and listening again and again; ii) prepare and present extended turns at seminars and tutorials; iii) carry out reading research in an efficient way, i.e. not reading and rereading again and again because the meaning escapes them in real time; and iv) produce written assignments.

The proposal of an alternative way of teaching English at the Faculty of Psychology of UC considers almost all the comments and suggestions by Mckinley (2010) and Feyen (2013). Practices of intensive and extensive reading of major related articles, the writing of a synthesis of the article and the oral presentation of the summary, listening to conferences in English such as TEDTalks, to peers and instructors' oral presentations, taking notes in real time, sharing the information with peers and instructors, participating in PSYTalks\&Music, and so on are the principal teaching and learning activities of this new and unconventional English Program. It is our belief that reading in English is being promoted at the Faculty of Psychology among students and staff, and it is already noticed that almost 30\% of the academic staff apply the reading of English research papers in their own subjects. Additionally, we have seen students are willing to spend time on their own browsing the web to identify subject related articles of their interest. It is also worth noting that participants mentioned that the most important activities that helped them learn English were i) listening (41\%); writing (41\%), reading (39\%) and speaking (25\%). Likewise, students stated that the methodology used in their English classes was good (36\%). However, there were also comments that this methodology needs to include more grammar explanations (15\%), less journal writing (9\%), improvement in the instruction (7\%) and be more dynamic $(6 \%)$ among others.

Meyer (2014), from the University of New Mexico, in her Language Evaluation Report indicated that English courses offered at the Faculty of Psychology seem to address many of the B2 language competencies, though they focus only on academic texts in the Psychology disciplines, not on texts that discuss a wide range of subjects as required by the B2 competencies. After finding out one of these setbacks, the implementation of a variety of general English material has been introduced via reading assignments on the readtheory.org platform and diverse topics in journals.

To sum up, our contention is that a new and viable alternative of teaching English at the university level has been identified which obviously needs to be in constant evaluation and improvement. With respect to the latter, it is believed that participant comments are crucial elements to be considered in the continuous improvement of the new and unconventional EFL teaching approach introduced at the Faculty of Psychology of UC.

\section{CONCLUSIONS}

In contradiction with the past, in university environments, it is more and more recognized that knowledge of English, as a second language is a must. Globalization and the fact that most research papers worldwide are published in English are responsible for the increasing need to strengthen at the university level in non-native speaking English countries, like Ecuador, the training in EFL. The traditional model of language education, which classically is teacher centered, is partly responsible for the low proficiency level of English of university students at graduation. Strong engagement of the students in the instruction process will not only lead to an increased interest of the students to study English but in an increased proficiency of this language. The Faculty of Psychology of UC drastically choose to introduce as from the second semester of 2014 for a modified approach to English instruction 
focusing on the one hand the linking of EFL instruction to the reading and analysis of major related English articles, and on the other hand on the continuous learning outside the class via a variety of video hosting sites and a flipping oriented methodology. The students freely select a major related article, are requested to read it, summarize it, present it and discuss it with classmates under the supervision of the EFL instructor. At the end of the second semester of 2016, a qualitative evaluation of the impressions of the students was made, which is presented herein. Overall the students seem to be very enthusiastic about the new approach, which in addition to improving their motivation and English proficiency are experienced as an eye opener for research.

Whereas the cross-sectional survey primarily aimed to spot the students response to the modified EFL instruction at the Faculty of Psychology, it is evident that in future a longitudinal qualitativequantitative study should be conducted to assess the trend in the students' interest regarding the new instruction approach as well as the evolution in the students' English language proficiency. Such quasiexperimental study will also highlight the benefits and shortcomings of the modified instruction approach and help the staff to continuous upgrade the EFL training.

\section{REFERENCES}

Brevik LM (2014). Making implicit practice explicit: How do upper secondary teachers describe their reading comprehension strategies instruction? International Journal of Educational Research 67:52-66

Brevick L, Olsen R, Hellekjaer G, 2016. The complexity of second language reading: Investigating the L1-L2 relationship. Reading in a Foreign Language 28(2):161-182

CES (2016). Codificado del Régimen Académico del 4 de mayo del 2016, articulo 31, p.21. Consejo de Educación Superior, Quito, Ecuador

Duke NK, Pearson PD, Strachan SL, Billman AK (2011). Essential elements of fostering and teaching reading comprehension. In: Samuels SJ, Farstrup AE (Eds.), What research has to say about reading instruction ( $4^{\text {th }}$ ed.) (pp. 51-93). Newark, NJ: International Reading Association

Feyen J (2013). How to bring research into the classroom. From "Universidad de docencia a Universidad de docencia con investigación”. PowerPoint Presentation (11 pp), Dirección de Investigación, Universidad de Cuenca

Feyen J (2016). Improving English language skills of academicians and researchers of the University of Cuenca. Dirección de Investigación de la Universidad de Cuenca (DIUC). Unpublished manuscript

Krashen S (2004). Free voluntary reading: New research, applications, and controversies. RELC Conference, Singapore, 9 pp. Available at http://www.sdkrashen.com/content/articles/ singapore.pdf

Matute VH (2005). English syllabus proposal for teaching English as a foreign language in the San Jerónimo and Antisana Private Kindergarten, Pintag. Undergraduate thesis, Applied Linguistics in English Career, Universidad de las Fuerzas Armadas (ESPE), Ecuador, 122 pp

Meyer L (2014). Progress Report of the Evaluation of the English Language Program at the Universidad de Cuenca, Ecuador. Department of Language, Literacy \& Sociocultural Studies, and Latin American Programs in Education (LAPE). College of Education, University of New Mexico, Albuquerque, NM, USA

Mckinley J (2010). English language writing centres in Japanese universities: What do students really need? Studies in Self-Access Learning Journal 1(1):15-30

Menezes V (2013). Second language acquisition: Reconciling theories. Graduate program in linguistic studies, Federal University of Minas Gerais, Belo Horizonte, Brazil. Open Journal of Applied Sciences 3:404-412 
Norwegian Directorate for Education and Training (2010). Kartleggingsprøve i engelsk for vgl. Veiledning [Mapping tests in English for upper secondary school year 1. A guide]. Oslo, Norway: Author

Pluck G (2013). Teaching psychology through English. Incidental improvement in academic reading comprehension. Journal of Educational Services in Psychology LXV(1):38-42

Pop A-M, Sim M-A (2013). Benefits of English Language Learning - Language proficiency certificates: A prerequisite for the business graduate. Department of International Business, Faculty of Economic Sciences, University of Oradea, Oradea, Romania. JEL classification: Y091, pp. 167-176. Available at http://anale.steconomiceuoradea.ro/volume/2013/n2/016.pdf

Richard JC, Schmidt R (Eds.) (2002). Longman dictionary of language teaching and applied linguistics ( $3^{\text {rd }}$ ed.) London, UK: Longman, pp. 193-194

Trim J, Coste D, North B, Sheils J (2001). Gemeinsamer europäischer referenz-rahmen für sprachen: lernen, lehren, beurteilen. Berlin, Germany: Langenscheidt

Tsai J (2006). Connecting reading and writing in college EFL courses. The Internet TESL Journal XII(12). tsai.139 [-at-] osu.edu. Ohio State University (Ohio, USA). Available at http://iteslj.org/Articles/Tsai-ReadingWritingConnection.html 